https://doi.org/10.46344/JBINO.2020.v09i05.35

\title{
PREVALENCE OF POSTPARTUM DEPRESSION AMONG POSTNATAL MOTHERS ATTENDING IN TEACHING HOSPITAL BIRGUNJ
}

\author{
Kabita Pathak \\ Lecturer (Psychiatrics Nursing) \\ National Medical College Nursing Campus Birgunj,Nepal \\ Email: pathakkabita59@gmail.com
}

\section{INTRODUCTION}

Post partum depression is depression that occurs soon after having a baby. Some Health professionals call it postpartum non psychotic depression. The postpartum Blues are considered as normal part of early motherhood and usually goes away within 10 days after deliver. However some women has worse symptom that last longer. This is called postpartum depression. (Subedi, 2015)

Postpartum depression is one of the highest incidence problems among postpartum mental health disturbances which emerges at the 2-8 weeks of postnatal period, can continue up to 1 year, and has ability to transform to psychosis. (Tambang, Turan,Tolum \&amp; Can, 2018)

Worldwide, statistics shows that 450 million people are seriously affected by neurological and mental illness ranking depression as the fourth principal cause for disability and premature deaths and by the year 2020, depression is predicted to be the second leading cause of disability. Globally, about 10\% of pregnant women and $13 \%$ of women who just gave birth are suffering from mental health problems. It is higher in developing countries where $15.5 \%$ develop mental illness during pregnancy and $19.8 \%$ after childbirth continuing to affect the welfare of mothers, their babies, partners and family members. (Fantahun, Cherie, Deribe \&amp; Leul, 2018)

\section{Objectives of the study}

\section{General objective:}

The general objective of the study was to assess the prevalence of postpartum depression among postnatal mothers attending in Teaching Hospital, Birgunj.

\section{Specific objectives:}


The specific objectives of the study were:

To assess the prevalence of postpartum depression among postnatal mothers attending in Teaching Hospital Birgunj

To determine the association between prevalence and selected socio-demographic variables

\section{Significance of the study}

The findings will help to estimate the prevalence of postpartum depression among postnatal mothers.

The findings will help to identify early sign and symptom of postpartum depression among postnatal mothers.

The findings will help to prevent the progression of postpartum depression among postnatal mother.

\section{METHODOLOGY}

\section{Research Design}

A descriptive cross sectional study design was used for the study to find out prevalence of postpartum depression among postnatal mothers attending in Teaching Hospital, Birgunj.

Sampling

Sample Size
The sample size was calculated based on the prevalence of postpartum depression that was $15.2 \%$ (Maharjan, 2018). By considering the operational definition and inclusion criteria sample population was drawn.

\section{Ethical Consideration}

Formal approval was obtained by the researcher from Institutional Review Committee of National Medical College Teaching Hospital.

Formal permission was taken from the Hospital Director of National Medical College Teaching Hospital.

Written informed consent from each postnatal mother prior to data collection was taken.

Privacy, anonymity and confidentiality of all participants was maintained.

Human dignity was maintained by allowing the respondent to quit the researcher whenever they want to leave.

\section{Findings of the study}

The findings of the conducted study are discussed as follows:

Regarding Socio-demographic characteristics, it is found that most $(63.7 \%)$ of the postnatal mothers were from the age group less than 
25 years. Similarly more than half (61.8\%) of the postnatal mothers were Hindu and more than half (57.8\%) of the postnatal mothers were residing in urban area. Likewise among 102 postnatal mothers $36.3 \%$ were educated up to secondary level. More than $90 \%$ i.e. $90.2 \%$ of the postnatal mothers were homemaker. Likewise maximum (36.3\%) of the postnatal mothers had two children. Concerning the type of the family, majority $(82.4 \%)$ of the postpartum mothers had joint family. Likewise nearly half $(45.1 \%)$ of the postnatal mothers had monthly income of family between 10000- 200000. Likewise maximum (89.2\%) of the postnatal mothers delivered baby in hospital. Likewise nearly half (48\%) of postnatal mothers had their baby of one week. Likewise majority (63.7\%) of the postnatal mothers had given birth to a male baby.

Based on the cutoff point of Edinburgh postnatal depression scale $\geq 13,7.8 \%$ of the respondents had probable depression, $7.8 \%$ of the respondents of the respondents had fairly high possibility of depression, $12.7 \%$ of the respondents had possible depression and had $71.6 \%$ had depression not likely i.e. no depression. On the contrary, a recent study was conducted by Maharjan (2018) in Janaki Medical College and
Teaching Hospital among 330 postpartum mothers, which revealed that the prevalence of depressive symptoms was $15.2 \%$.

On the basis of the finding of the present study it is concluded that less than one fourth of the postnatal mothers had probable depression and fairly high possibility of postpartum depression. It is found that there is no any significant association between the prevalence of postpartum depression and selected socio-demographic variables.

By identifying and diagnosing the symptoms at an early stage can hopefully recover the women within a year and the ones in the morbid state can be helped to seek the health professional.

\section{Conclusion}

On the basis of the finding of the present study it is concluded that less than one fourth of the postnatal mothers had probable depression and fairly high possibility of postpartum depression. It is found that there is no any significant association between the prevalence of postpartum depression and selected socio-demographic variables.

By identifying and diagnosing the symptoms at an early stage can 
hopefully recover the women within a year and the ones in the morbid state can be helped to seek the health professional.

\section{REFERENCES}

Chinwa, A, T., et al. (2015). Postpartum depression among mothers seen in Enugu, Southeast Nigeria: an undocumented issue. Pan African Medical journal, 23(180).. Retrieved from, http://www.panafrican-medjournal.com/content/article/2 3/180/full

DOI: doi:10.11604/pamj.2016.2

3.180.8244

Subedi,D.(2015).Mental Health and

Psychiatric

Nursing.

Kathmandu:

Makalu

Publication Pvt.Ltd

Fantahun,A.,

Cherie,A., \&

Deribe,L.(2016).Prevalence

And Factors Associated With

Postpartum Depression Among Mothers Attending Public Health Centers of Addidas Abab, Ethiopia. Clinical Practice And Epidemiology in Mental Health, 14,196-206. Retrieved from ncbi.nlm.nih.gov/pmc/articles/ Pmc6131316/full text

Agrawaal,A., Rao,P,A., \& Narayan,P. (2018). Prevalence and
Predictors of Postpartum Depression among Mothers in the Rural Areas of Udupi, Taluk, India: A Cross Sectional Study. Clinical Epidemiological and Global Health. Retrieved from, https://cegh.net/article/S22133984 (18)30006X/fulltext

Maharjan,L,P., Lamichhane,S., Shrestha,P,D., Mathias,J., Gautam,K,R., \& Shah,K,S. (2018). Prevalence and Factors Associated with Depressive Symptoms Among Postpartum Mothers in Dhanusha District of Nepal. Sleep And Hypnosis, A Journal of Clinical Neuroscience and Pychopathology, 21(1), 60-80. Retrieved from http://www.sleepandhypnosis. org/ing/abstract.aspx? MkID=2 $\underline{75}$

Cox,J,L., Holden,J., \& Sagovsky ,R. (1987). Detection of postnatal depression, Development of 10 item Edinburgh Postnatal Depression Scale .The British Journal Of Psychitry, 150(6), 782-786. Retrieved from, https://www.cambridge.org/c ore/journals/the-british-journal-

of-

psychiatry/article/detectionof-postnatal depression/E18BC62858DBF264 OC33DCC8B572F02A 
Kunwar,D., Caorey,E,K., Sharma,P., \& Risal, A. (2015). Screening for Postpartum Depression and Associated Factors Among Women Who Delivered at a University Hospital, Nepal. Kathmandu University Medical Journal, 49(1), 44-48. Retrieved from,

https://www.researchgate.net /publication/283302576

Giri,R,K., Khatri,R,B., Mishra,S,R., Khanal,V., Sharma,U,D., Gartaula,R,P.(2015).

Prevalence and Factors associated with Depressive Symptoms among Postpartum Mothers in Nepal. Bio Med Central,8(11).Retrieved from, https://bmcresnotes.biomedc entral.com/articles/10.1186/s 1 3104-015-1074-3. DOI: 10.1 186/s 13104-015-1074-3

Bansal,S,C.,

Ganjiwale, J,D., Nimbalkar,S,M., \& Kharod,N,M.(2018).Screening for Postpartum Depression in Neonatal Intensive Care Unit and Post Natal Ward with its Impact on Newborn Care Practices :A Hospital Based Study. Journal Of Clinical And Diagnostic Research, 12(8). Retrieved from, https://www.researchgate.net Lpublication/326894959. DOI
10.7860/JCDR/2018/28153.118 44

Shriram, V., Shah,P,B., Rani,M,A., \& Sathiyasekaran, B,W,C.(2019).

A Community Based Study of Postpartum Depression. Indian Journal of Social Psychiatry,35(1),64-68.

Retrieved from http://www.indjsp.org/text.asp ?? DOI:10.4103/ijsp.ijsp_13_18

Melinamani S., Hitnal,S., \& Patil,A.(2015).Assessment of Prevalence of Postnatal Depression among Postnatal Mothers. IOSR Journal of Nursing and Health Sciences,4(3), 57-60. Retrieved from,

www.iosriournals.org/iosrinhs/papers/vol4issue3/Version-4/J04345760.pdf DOI: 10.9790/1959-04345760

Tambang,H., Tarun,Z., Tolun,S., \& Can,R. (2018). Perceived Social Support and Depression Levels of Women in Postpartum Period in Hatay,Turkey. Nigerian Journal of Clincal Practice, 21(11) 1525-1530. Retrieved from, http://www.njcponline.com/ $\dagger$ ext.asp?2018/21/1 1/1525/2451 79

DOI: 10.4103/njcp.njcp_285_17 John, V,G.(2017).Predictors of Postpartum Depression among Women in Karachi, Pakistan. 
Loma Linda University Electronic thesis, Dissertion and projects, 476. Retrieved from, https://scholarsrepository.llu.ed u/etd/476/full text

Kerie,S. Menberu,M.,

\&

Niguse,W.(2017). Prevalence and Associated Factors of Postpartum Depression in Southwest Ethiopia: A Cross Sectional Study. BMC Research Notes, $11(623)$. Retrieved from https://bmcresnotes.biomedc entral.com/articles/10.1186/s 1 3104-018-3730-x

Mishra ,D., Shakya,D,V., Pathak,R,S., \& Mishra,S.(2019). Postpartum Depression among Women Attending Maternal and Child Health Clinic in Selected Hospital of Nepal. Journal of Manmohan Institute of Health Sciences (JMMIHS), 5(1) , 2711. Retrieved from, https://www.nepjol.info/index. php/JMMIHS/article/view/2406 9

DOI:

https://doi.org/10.3126/jmmihs. v5il.24069

Chavez,M,D., \& Dichoso,M,C. (2014). Prevalence of Postpartum Depression among Mothers Who Delivered in a Tertiary Hospital. PJOG, 38(3), 15-21. Retrieved from, https://www.pjog.org/downlo ad.php?id $=15$

Berner,A., Burgut, F,T, Ghuloum, S., \& Sheikh,J.(2012). A study of potpartum depression in fast developing country: Prevalence and associated factors. Internaational Journal of Psychiatry in Medicine, 43(4). Retrieved from, https://Journals.Sageplus.com. Ldoi/abs/10.2190/PM.43.

Sherkhane,M., \& Sharma,P.(2018). Depression in postpartum women residing in urban slums using Patient Health Questionnaire-9. International Journal of Medical Science and Public Health, 8(4), 286291. Retrieved from, http://www.ijmsph.com . DOI: 10.5455ijmsph.2019.1133720180 2032019

Kishore, K., Udaypur,S.E., \& Mallapur, M.D.(2016). An epidemiological study of postnatal depression among women availing maternal health services in rural areas of Belagavi, Karnataka, India. International Journal of Community Medicine and Public Health, 4(3), 759-763. Retrieved from, http://www.ijcmph.com/index .php/ijcmph/article/viewFile/3 79/953 - PDF file. DOI: 
http://dx.doi.org/10.18203/239 4-6040.ijcmph20170754

Modi, V.P., Parikh, M.N., \& Valipay, S.K.(2018). A study on prevalence of postpartum depression and correlation with risk factors. Ann Indian Psychiatry, 2(1), 27-32. Retrieved from, http://www.anip.co.in/text.asp ?2018/2/1/27/232047.

DOI: 10.4103/aip.aip_48_17

Shewangzaw,A., Tadesse,B., Ashani,T., Misgana, T., \& Shewasinad, S.(2015). Prevalence of Postpartum Depression and Associated Factors among Postnatal Women Attending At Hiwot Fana Specialized University Hospital, Harar, East Ethiopia, 2015/2016. = Journal of Reproductive System and Sexual Disorders, 1(1). Retrieved from, https://lupinepublishers.com/r eproductive-medicinejournal/fulltext

Kalar et.al.(2010). Prevalence and Predictors of Postnatal Depression in Mothers of Karachi. International Journal of Collaborative Research on Internal Medicine \& Public Health, 4(5), 830-839. Retrieved from,

https://internalmedicine.imed pub.com/prevalence-and- predictors-of-postnataldepression-in mothers of Karachi

Fanatun,A., Cherie, A., Deribe, $L$. (2016). Prevalence and Factors Associated with Postpartum Depression Among Mothers Attending Public Health Centers of Addis Ababa, Ethiopia, 2016.Clinical Practice and Epidemiology in Mental Health,4, 196-206. Retrieved from, https://benthamopen.com/FU LLTEXT/CPEMH-14-196. DOI: 10.2174/1745017901814010196

Ahmad,M., Butt,M,S., Umar, B., Arshad, H,S., Iftikhar, N., \& Maqusood, U. (2015). Prevalence of postpartum depression in an urban setting . Biomedical Research, 26 (4), 765-770. Retrieved from, https://www.alliedacademies. org/articles/prevalence-ofpostpartum-depression-in-anurban-setting.html

Yusuff,A.S.M., Tang, L., Binns, C.W., \& Lee, A.H(2010) .Prevalence and risk factors of postpartum depression in Sabah, Malaysia:A cohort study. Women Birth, 28(1), 25-29. Retrieved from, https://doi.org/10.1016/j.womb i.2014.11.002 